\title{
Assessing Soil Nutrient Additions through Different Composting Techniques in Northern Ethiopia
}

\author{
Kassa Teka*, Tesfay Berihu, Hailemariam Amdu, Tigist Araya and Samuel \\ Nigussie
}

Department of Land Resources Management and Environmental protection, Mekelle University, P.O. Box 231, Mekelle, Tigray, Ethiopia (*kassateka@yahoo.com)

\begin{abstract}
The use of vermi-compost in northern Ethiopia is not a common practice. It is, therefore, important to understand the possible impediments through studying its chemical and biological properties and its extra contribution compared to other composting techniques. Four compost types (vermi-compost, conventional compost, farmers' compost and community nursery compost) with three replications were used in this study. The farmers' and community nursery compost samples were collected from different places in Tigray; whereas, the vermi- and conventional composts were prepared at Mekelle University following a standard composting procedure. Six major composting materials were identified in the visited sites from farmers' and community nursery foremen's interview. These composting materials were also used for the vermi- and conventional composting. Twelve composite compost samples were taken for analysis of macro- and micro-nutrients. The results of the experiment showed that for all treatments, despite of having high content of total $\mathrm{C}(5.04-10.67 \%)$, the $\mathrm{C} / \mathrm{N}$ ratio $(12.19-$ 12.22) was low. This suggests that as the $\mathrm{C} / \mathrm{N}$ ratio is lower than the threshold $(<30)$, mineralization is faster, nutrients eventually become available and a large amount of $\mathrm{N}$ is lost. Soil pH, exchangeable Magnesium (ex.Mg), exchangeable Potassium (ex.P), available Phosphorus (ava.P), and Cation Exchange Capacity (CEC) showed significant differences among the different composting techniques. Among the selected compost types, ex.Mg, ex.Ca and av.P were higher for vermi-compost. The lowest was recorded in community nursery compost. The use of vermi-compost is, therefore, very helpful in terms of providing beneficial soil nutrients as compared to other compost types.
\end{abstract}

Keywords: Conventional compost, Vermi-compost, farmers' compost, Nursery compost, Macronutrients, Micro-nutrients.

\section{INTRODUCTION}

Agriculture is the backbone of the Ethiopian economy accounting for $47.5 \%$ of the GDP (World Bank, 2007). The performance of agriculture depends on natural factors and the intensity of agricultural inputs (Sinha et al., 2010; Bezabih et al., 2010). The vast area of Africa in general and Ethiopia in particular is characterized by low soil fertility, high soil degradation, rain-fed and fragmented land holding, extremely low external inputs such as fertilizer and agro-chemicals, and the use of traditional farming techniques (Bezabih et al., 2010). The scientific community all over the world is, therefore, desperately looking for an 'economically viable and environmentally 
sustainable' option, which would not only 'maintain' but also 'enhance' farm production per hectare of available land (Sinha et al., 2010).

Organic farming systems with the aid of various nutrients of biological origin such as compost are thought to be the answer for the 'food safety and farm security' in the future (Hoitink and Fahy, 1986; Weltzien, 1989; De Brito et al., 1995; Scheuerell and Mahaffee, 2002; Hailu and Edwards, 2006; Mugwe et al., 2007; SSNC, 2008; Hailu, 2010). Composts contain plenty of 'beneficial soil microbes' which help in 'soil regeneration' and 'fertility improvement' (Weltzien, 1989; De Brito et al., 1995) and protect them from degradation while also promoting growth in plants (Hoitink and Fahy, 1986; Scheuerell and Mahaffee, 2002). Compost is becoming widely used by many farmers in the Sub-Saharan Africa, including the study area, to improve soil fertility and crop production (Mugwe et al., 2007; Hailu, 2010). Compost has been used by about 25 percent farmers in Tigray (Hailu and Edwards, 2006; SSNC, 2008).

Nowadays, the use of earthworms as a composting technique is also gaining popularity. This method is commonly known as vermi-composting (Edwards, 1998), the process by which worms are used to convert organic materials into a humus-like material known as vermi-compost. Aira et al. (2002) also described the vermicomposting process as "bio-oxidation and stabilization of organic material involving the joint actions of earthworms (such as Eisenia foetida, Eudrilus eugeniae and Perionyx excavates) and (mesophilic) microorganisms". Eisenia foetida is the most widely used earthworm due to its efficiency in this process (Capistrn et al., 2001).

Conventional composting and vermi-composting are quite distinct processes particularly with respect to optimum temperatures for each process and the type of decomposer microbial communities that predominate during active processing (Tomati and Galli, 1995; Sinha, 2009). While 'thermophilic bacteria' predominate in conventional composting, 'mesophilic bacteria \& fungi' predominate in vermicomposting (Sinha et al., 2010). Many researchers (e.g. Perz-Murcia et al., 2006; Sinha et al., 2010) have compared the benefits of vermicomposting with the conventional composting. They concluded that vermi-compost provided extra nitrogen (2-3\%), potassium (1.85-2.25\%), phosphorus (1.55-2.25\%) and micronutrients. Kale (1998) reported as high as $7.37 \%$ nitrogen $(\mathrm{N})$ and $19.58 \%$ phosphorus as $\mathrm{P}_{2} \mathrm{O}_{5}$ in worm's vermicast. Atiyeh et al. (2000a) revealed that the conventional compost was higher in 'ammonium', while the vermicompost tended to be higher in 'nitrates', which is the more available form of nitrogen. Phosphorus $(\mathrm{P})$, potassium $(\mathrm{K})$, sulfur $(\mathrm{S})$ and magnesium $(\mathrm{Mg})$ were significantly increased by 
adding vermi-compost as compared to conventional compost to soil (Atiyeh et al., 2000b). In Argentina, farmers who use vermi-compost consider it seven times richer than conventional composts in nutrients and growth promoting values (Munroe, 2007).

Despite the benefits described above, the use of vermi-compost in northern Ethiopia is not commonly known. Moreover, most of the above studies focused on limited composting materials and composting techniques. However, the material and techniques used for composting by farmers differ from those used in nursery sites and research/academic institutions. The nutrient content of these materials is not well known in these drier areas. Furthermore, the extra contributions of vermi-compost as compared to the other compost types prepared by different users (farmers, nursery and research/academic) were not assessed.

The objectives of this study were: 1) to understand the possible impediments and benefits of the composting materials and techniques by studying their chemical and biological properties; 2) to assess the extra contributions of vermi-compost as compared to the other compost types prepared by different users (farmers, nursery and research/academic). This study has, therefore, tried to include all available and commonly used composting techniques and composting materials in the Tigray region, northern Ethiopia.

\section{MATERIALS AND METHODS}

\subsection{Study area}

This study was conducted in selected areas (see Table 1 and Fig. 1) of Tigray region in the northern part of Ethiopia. The region has a total area of $54,572 \mathrm{~km}^{2}$ and is located between latitudes $12^{\circ} 15^{\prime} \mathrm{N}$ and $14^{\circ} 50^{\prime} \mathrm{N}$ and longitudes $36^{\circ} 27^{\prime} \mathrm{E}$ and $39^{\circ} 59^{\prime} \mathrm{E}$. The region has a diverse topography with an altitude that varies from about 500 meters above sea level in the Tekeze gorge to almost $4000 \mathrm{~m}$ above sea level in the Tibet Mountain (Kassa et al., 2014).

Based on the data obtained from the central statistical Agency (CSA) of Ethiopia published in 2008, Tigray has an estimated population of 4,565,000 of which 80.5 percent are rural inhabitants. The region has an estimated average density of 91.2 persons per $\mathrm{km}^{2}$ (CSA, 2008). Tigray is a semi-arid area characterized by sparse and highly uneven rainfall distribution and by frequent drought. The main rainfall season called 'kiremti' starts in mid June and ends in the beginning of September. In some parts of the region, there is a short rainy season called 'belg' that falls in March, April and May. Rainfall in the region is highly variable temporally and 
spatially. Average rainfall varies from about $200 \mathrm{~mm}$ in the northeast lowlands to over $1000 \mathrm{~mm}$ in the southwest highlands (Fredu, 2008). In most parts of Tigray region, 46 - 73 percent of the rainfall is confined into only July and August months (Belay, 1996; Kassa et al., 2014).

There is no systematic soil survey undertaken for the whole of Tigray Region. Only few researchers such as Hunting (1975), Van de Wauw et al. (2008), Nyssen et al. (2008), Kassa et al. (2010), and Kassa and Mulu (2012) have carried spot level soil survey. Based on these researches, the major soils of the region are identified as Cambisols, Luvisols, Rendzinas, Lithosols (Leptosols), Fluvisols, Nitosols, Arenosols, Vertisols, Xerosols, Regosols, Calcisols, Fluvisols and Andosols.

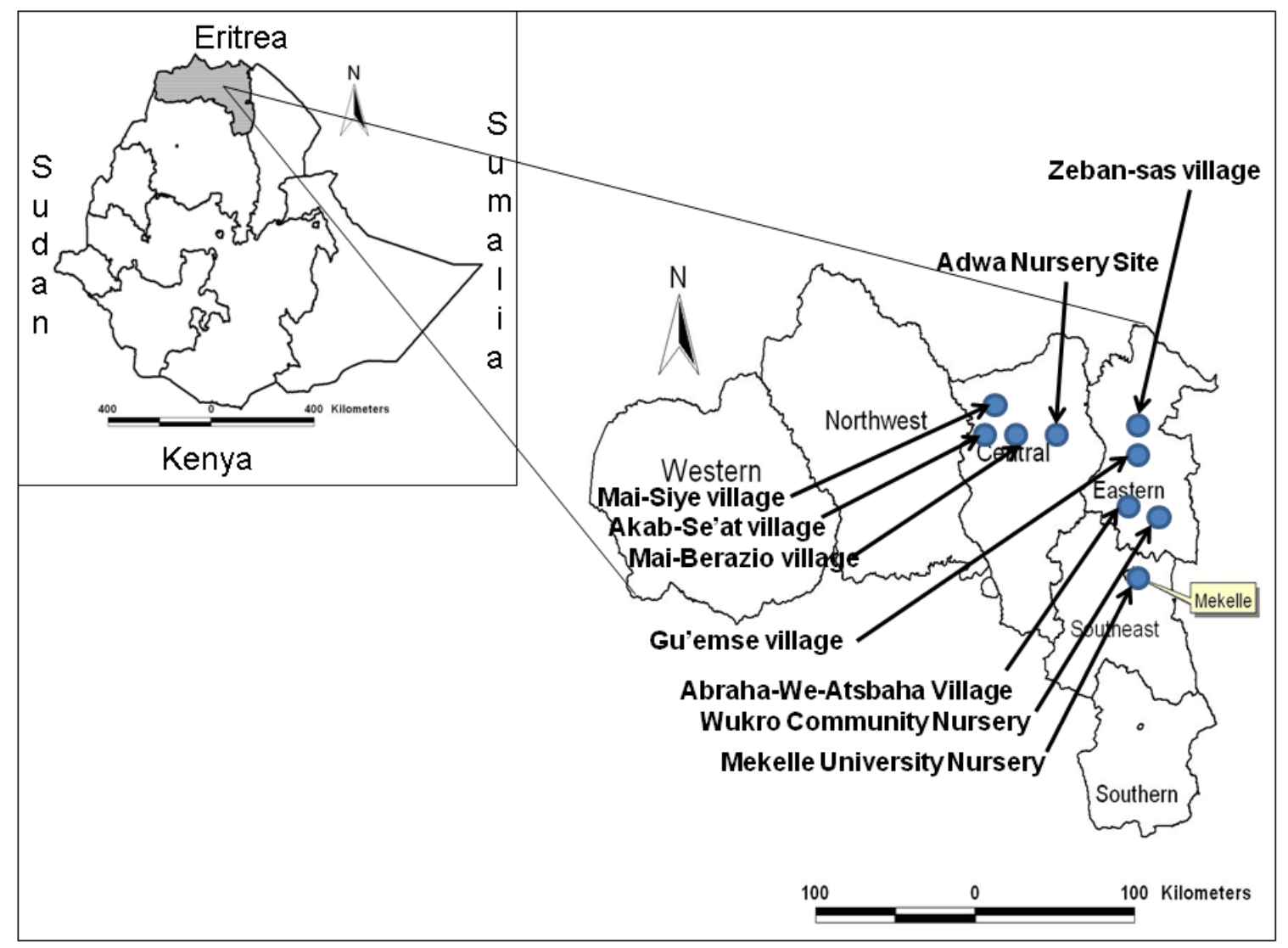

Figure 1. Location map of the study sites in Tigray and Ethiopia. 
Table 1. Approximate location of the compost sampling sites (village center point location).

\begin{tabular}{|lllccc|}
\hline Site name & District & Zone & Latitude $(\boldsymbol{N})$ & Longitude (E) & Elevation (m) \\
\hline Mai-Berazio village & Tahtay Maichew & Central & $14^{\circ} 07^{\prime} 21^{\prime \prime}$ & $38^{\circ} 32^{\prime} 55^{\prime \prime}$ & 2217 \\
\hline Akab-Se'at village & Tahtay Maichew & Central & $14^{\circ} 05^{\prime} 48^{\prime \prime}$ & $38^{\circ} 31^{\prime} 24^{\prime \prime}$ & 2252 \\
\hline Mai-Siye village & Tahtay Maichew & Central & $14^{\circ} 08^{\prime} 13^{\prime \prime}$ & $38^{\circ} 35^{\prime} 19^{\prime \prime}$ & 2203 \\
\hline Zeban-sas village & Saesie'-tsae'damba & Eastern & $14^{\circ} 05^{\prime} 02^{\prime \prime}$ & $39^{\circ} 36^{\prime} 10^{\prime \prime}$ & 2583 \\
\hline Gu'emse village & Saesie'-tsae'damba & Eastern & $14^{\circ} 01^{\prime} 52^{\prime \prime}$ & $39^{\circ} 36^{\prime} 35^{\prime \prime}$ & 2573 \\
\hline Abraha-we-atsbaha village & Kilte-Awulaelo & Eastern & $13^{\circ} 50^{\prime} 49^{\prime \prime}$ & $39^{\circ} 32^{\prime} 04^{\prime \prime}$ & 2007 \\
\hline Adwa community Nursery & Adwa & Central & $14^{\circ} 10^{\prime} 39^{\prime \prime}$ & $38^{\circ} 52^{\prime} 41^{\prime \prime}$ & 1907 \\
\hline Wukro community nursery & Wukro & Eastern & $13^{\circ} 48^{\prime} 24^{\prime \prime}$ & $39^{\circ} 36^{\prime} 13^{\prime \prime}$ & 2006 \\
\hline Mekelle University Nursery & Debub & Mekelle & $13^{\circ} 28^{\prime} 46^{\prime \prime}$ & $39^{\circ} 29^{\prime} 20^{\prime \prime}$ & 2218 \\
\hline
\end{tabular}

About 85 percent of the population in Tigray earns their living from agricultural activities (Girmay, 2006; Kassa et al., 2014). Agriculture in Tigray consists of crop husbandry, animal husbandry and mixed farming (CSA, 2008; Kassa et al., 2014). Smallholder agriculture predominates with an average land holding of less than one hectare per family (Hailu, 2010; Kassa et al., 2010; Kassa and Mulu, 2012). Agricultural systems in the region are characterized by traditional technology based entirely on animal traction and rain fed agriculture. The use of small scale irrigation is also growing since the last two decades in the region (Kassa et al., 2014). Nigussie et al. (2006) and Gebreyohannes et al. (2012) reported that 54 large dams each with an average water storage capacity of 1-3.5 million cubic meters were constructed in the years between 1994 and 2003. Following the 2002 drought year, small-scale household rainwater harvesting ponds were also introduced by the regional government (Kassa et al., 2014). The average crop yield is about 1 ton/ha (Kassa et al., 2014). This is less than the average national annual grain yield of 1.2 tons/ha (Abrar et al., 2004). Besides to crop production, livestock play important role in the life of rural households (CSA, 2008).

\subsection{Study method}

Various compost types (government, non-government and farmer managed) were visited in Tigray region (Table 1 and Fig. 1) in order to get an insight on the recent use of compost in the region, understand the compost preparation techniques and identify the commonly used composting materials. Farmers' managed composts were visited in Tahtay Maichew (MaiBrazio, Akab-se'at and Mai-Siye villages), Saesie'-tsae'damba (Zeban-sas and Gu'emse villages) and Kilte-Awulae'lo (Abraha-We-atsbaha village) districts. Moreover, Community/Government Nurseries in Adwa and Wukro districts, and the Nursery site of the College of Dryland Agriculture and Natural Resources in Mekelle University were visited. The 
composting experience and accessibility were the main criteria for selection of these sites. Unlike other areas in Tigray, farmers in Tahtay Maichew, Saesie'-tsae'damba and Abraha-We-Atsbaha dominantly use compost under a close follow-up of the Institute for Sustainable Development in collaboration with the offices of agriculture and rural development (Hailu, 2010). The Adwa community nursery, Wukro community nursery and Mekelle University nursery sites were among the old, well established and most accessible nursery sites in Tigray.

Six composite compost samples (3 from farmers' and 3 from nursery) were taken from these sites for chemical and biological analysis. The two compost types (Farmers' and nursery) were treated as treatments while the 3 sites in each treatment were blocks/replications. In each site/block (see table 1), 5-10 farmers' compost pits were randomly visited, sampled and composited to make one sample per site/block. Pit composting was the dominant composting technique with the pit size of about $1 \mathrm{~m} \mathrm{X} 1 \mathrm{~m} \mathrm{X} 1 \mathrm{~m}$. The composting materials used in each compost pit were identified through interviewing compost pit owners and nursery foremen. To get a better understanding on the representativeness of the composting techniques and composting materials, additional compost sites in Wukro St.Mary's college, Gormodo (Saesie'tsae'damba) nursery and Axum University were visited. The composting techniques and materials used for compost making were more or less similar with those of the study sites. The main composting materials in most of the observed sites were manure, dry grass, fresh grass/weeds, fresh soil, old compost and leftover vegetables. Except for Axum University (in which the source of manure was from cattle), the sources of manure in all sites were both cattle and poultry.

To evaluate the importance of vermi-compost, two additional compost types (vermi-compost and conventional/garden compost) were prepared. There was no prior information on the soil and composting materials; however, the six commonly used composting materials in the region were used in both the garden and vermi-compost treatments to avoid the variation which might exist due to the difference in composting materials. The difference should, therefore, be due to differences in composting technique, i.e. vermi- and conventional composting. Both compost types were prepared in Mekelle University nursery site.

For the vermi-compost, ten mobile wooden worm bins/propagators with $1 \mathrm{~m}$ width, $2 \mathrm{~m}$ length and $0.3 \mathrm{~m}$ height were prepared. These 10 bins were prepared with the objectives: 1) to have compost samples equivalent to the three layers in each conventional pit; 2) to rear the vermi- 
worms for future use, though it was not the immediate objective of this research work. These bins were filled with the six composting materials at the proportion of $2 \mathrm{~cm}$ fresh soil, $8 \mathrm{~cm}$ fresh grass/weed, $2 \mathrm{~cm}$ manure, $2 \mathrm{~cm}$ leftover vegetables, $1 \mathrm{~cm}$ old compost and $9 \mathrm{~cm}$ dry grass (Fig. 2a \& b) following the composting procedure proposed by ISD and EPA (2009). During preparation, tap water, the only available source of drinking water at the university was applied in each layer (3 liter/layer) to keep the material moist. To insure aeration and drainage, a $4 \mathrm{~cm}$ depth of gravel and sand was used as bedding material. About 500 adult Eisenia foetida worms accompanied by some (about 500 gram) old vermi-composted material, reared at the Mekelle University Nursery site, were inoculated to the surface (with in $2 \mathrm{~cm}$ ) of each bin/propagator after 5 days of composting.
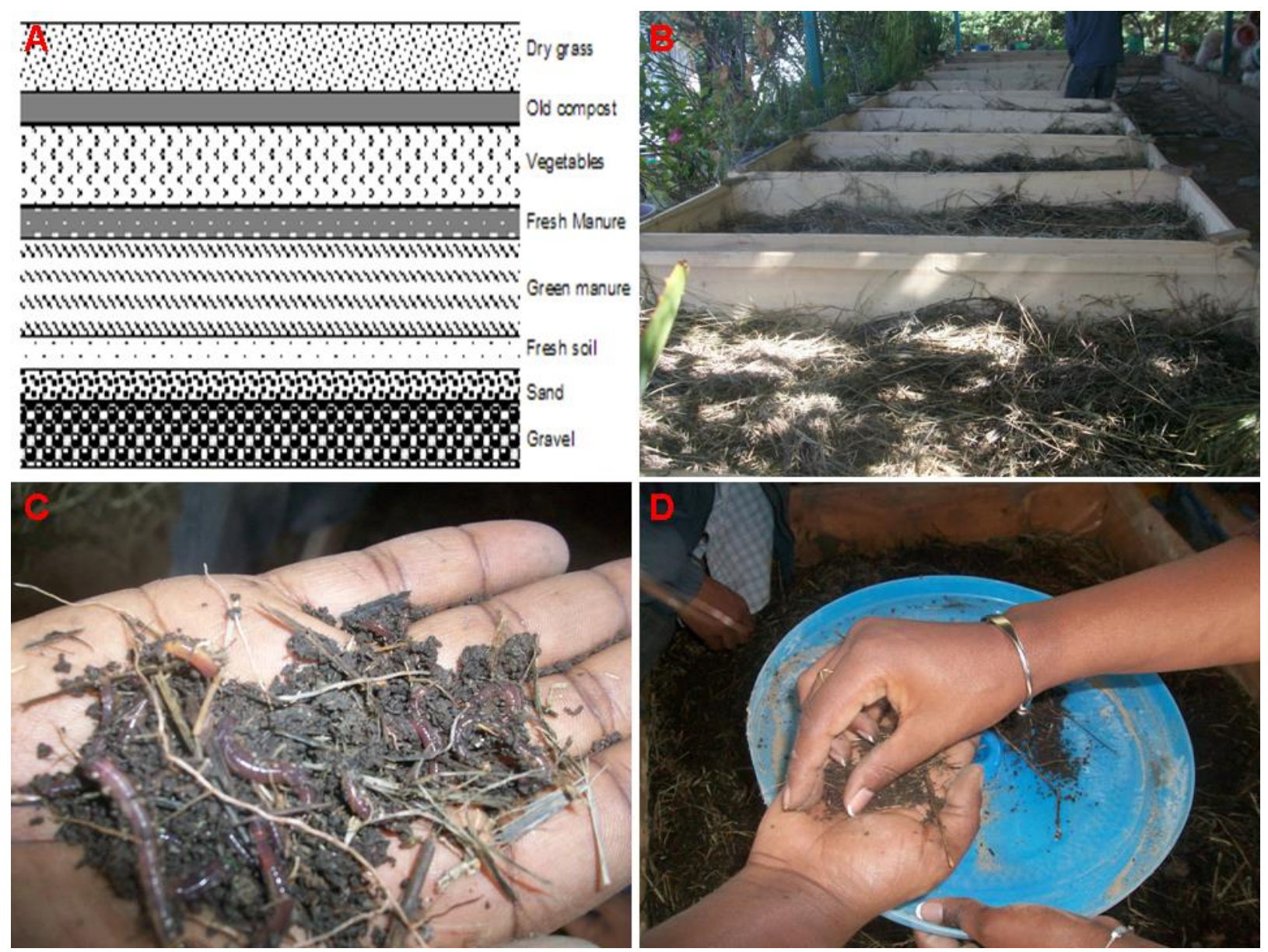

Figure 2. Composting material layer (a), vermi-composted bins (b), Eisenia foetida worms (c) and (d) old vermi-compost sampling.

For comparison on the amount of extra nutrients gained from vermi-composting, three conventional/garden compost pits with a size of each 1 X 1 X $1 \mathrm{~m}^{3}$ were dug (Fig. 3a) and filled 
with the same material and proportion (Fig. $3 b \& c$ ) in the same day with that of vermi-compost following the procedure proposed by ISD and EPA (2009). The six composting materials were repeated three times in the conventional compost pit. However, the arrangement of the compositing materials was a bit different depending on the nature of the composting technology used. As the worms in vermi-compost need air, the layers in the bin were arranged in such a way that the heavier materials were at the bottom whereas the lighter materials at the top. Whereas, the dry grass in the pit compost was at the bottom so as to keep moisture.
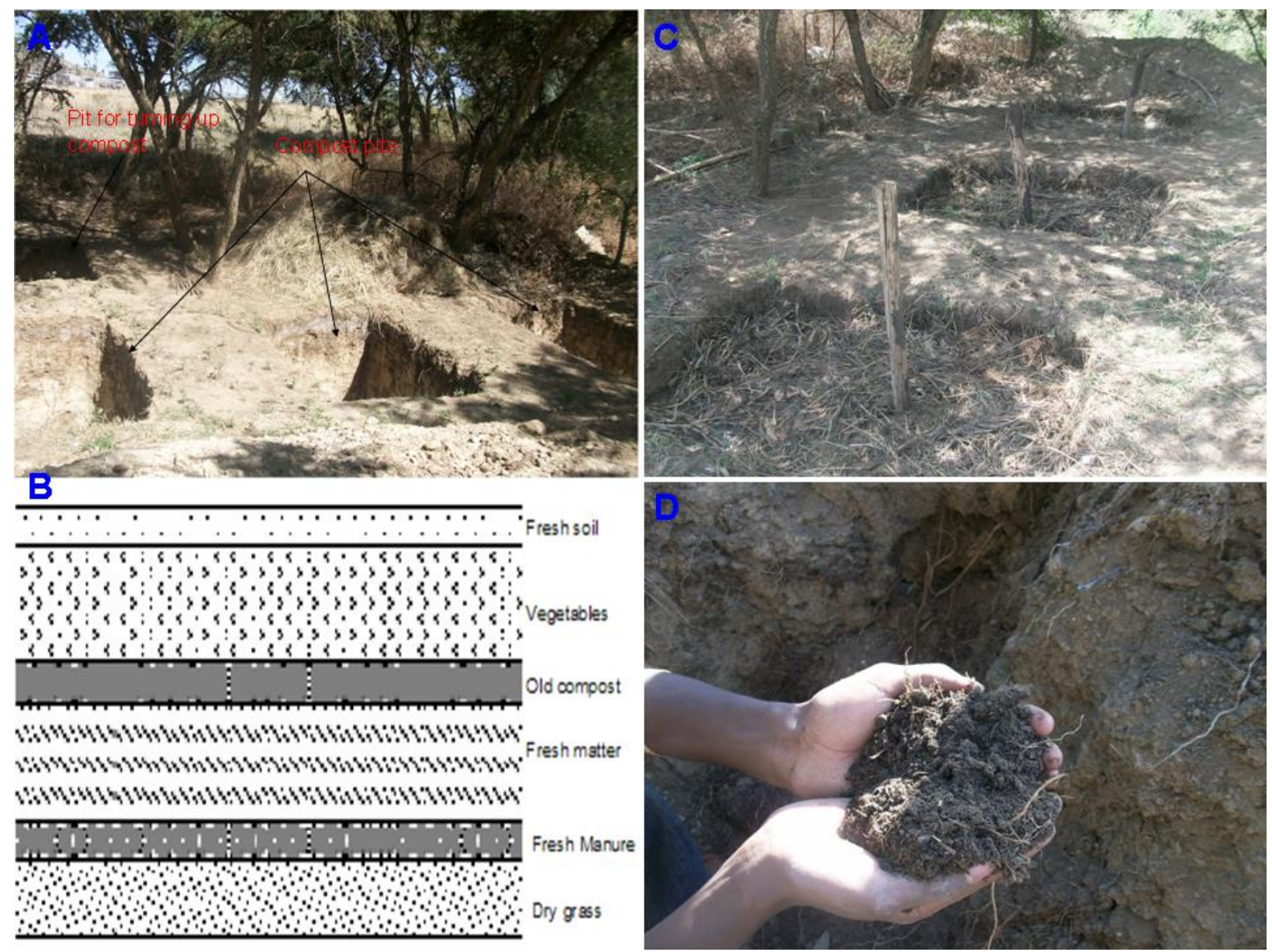

Figure 3. Compost pits made ready (a), composting materials (b) filled compost (c), matured compost (d).

After about 3 months (when the composts gave an earthy smell, dark color and un detectable original materials), three composite compost samples from each of the vermi-compost (systematically sampled from the $1^{\text {st }}$ three, middle three and last four bins) (Fig. 2d) and garden compost (Fig. 3d) were taken for chemical and biological analysis. In total, 12 compost samples were taken. The experimental design applied was a completely randomized block, with 4 
treatments (Farmers' compost, nursery compost, vermi-compost and conventional compost) and three replications. These samples were prepared following the procedure proposed by McKeague (1976). Tests primarily focus on the elements in most demand by crops, which are supplied by fertilizers: nitrogen $(\mathrm{N})$, phosphorus $(\mathrm{P})$, potassium $(\mathrm{K})$, calcium $(\mathrm{Ca})$ and magnesium $(\mathrm{Mg})$. Micronutrients such as iron $(\mathrm{Fe})$, Zinc $(\mathrm{Zn})$, manganese $(\mathrm{Mn})$ and copper $(\mathrm{Cu})$ were also measured. The Sodium (Na) content was also evaluated.

The modified Kjeldahl method (Christensen and Fulmer, 1927) was used to determine the total nitrogen (Nt) content of a soil. The sodium bicarbonate procedure of Olsen et al. (1954) was used to determine $\mathrm{P}$ availability. The cations $\mathrm{Na}^{+}, \mathrm{K}^{+}, \mathrm{Mg}^{+2}$ and $\mathrm{Ca}^{+2}$ were determined by Atomic Absorption Spectrometer (AAS). Micro - nutrients were analyzed using Aqua-regia (ISO, 1995). The unit of measurement (cations in milligram per kilogram of compost) was converted to percent $(\%)$ in order to make it comparable with the study of Kalantari et al. (2010) and Las Cruces (2001). As nutrient behavior in soils is governed by soil properties and environmental conditions, measurements of such properties is often required. These include $\mathrm{pH}$, salinity (EC) and organic matter $(\mathrm{OM})$. The $\mathrm{pH}$ and $\mathrm{EC}$ of the soil were measured in the supernatant suspension of a 1:5 soil: liquid (v/v) mixture (ISO, 1994). Soil pH was measured potentiometrically using an electronic $\mathrm{pH}$ meter (McLean, 1982). The data were subjected to an analysis of variances (ANOVA), using the statistical package SAS for Windows version 9.0.

\section{RESULTS AND DISCUSSION}

The chemical and biological properties of all compost treatments are presented in Tables 2, 3, and 4. Results of chemical analysis (Table 2) showed that the pH, ex.Mg, ava.P, ex.K and CEC had significant differences $(\mathrm{p}<0.05)$ among the treatments under investigation.

Table 2. Nutrient content comparison (at $\mathrm{p}<0.05)$ across all treatments.

\begin{tabular}{|lccc|}
\hline Soil property & Level of significance & Soil property & Level of significance \\
\hline $\mathrm{pH}$ & $0.0406^{\mathrm{a}}$ & $\mathrm{ava} . \mathrm{P}$ & $0.0329^{\mathrm{a}}$ \\
\hline $\mathrm{EC}$ & $0.1178^{\mathrm{ns}}$ & $\mathrm{Nt}$ & $1.66^{\mathrm{ns}}$ \\
\hline $\mathrm{CEC}$ & $0.025^{\mathrm{a}}$ & $\mathrm{OC}$ & $1.66^{\mathrm{ns}}$ \\
\hline exc.Ca & $0.2656^{\mathrm{ns}}$ & $\mathrm{Fe}$ & $1.56^{\mathrm{ns}}$ \\
\hline exc. $\mathrm{Mg}$ & $0.0472^{\mathrm{a}}$ & $\mathrm{Mn}$ & $1.17^{\mathrm{ns}}$ \\
\hline exc. $\mathrm{Na}$ & $0.5503^{\mathrm{ns}}$ & $\mathrm{Cu}$ & $1.17^{\mathrm{ns}}$ \\
\hline Exc.K & $0.0440^{\mathrm{a}}$ & $\mathrm{Zn}$ & $1.44^{\mathrm{ns}}$ \\
\hline
\end{tabular}

Key: ${ }^{n s}$ not significant $(P>0.05),{ }^{a}$ significant $(p<0.05)$. 
Both conventional and vermi-composts have yielded higher ava.P, OC, TN, ex.Mg and CEC with most of these values highest in vermi-compost while the lowest in nursery compost. These results are typical of what other researchers (e.g. Saradha, 1997) have found. This also corresponds with the findings of Kale (1998) who reported as high as $19.58 \%$ phosphorus in worm's vermicast. According to Satchel and Martin (1984), the passage of organic matter through the gut of worm results in phosphorus (P) converted to forms, which are more bioavailable to plants. Chaoui et al. (2003) also showed that vermi-composts were potentially better growth medium amendment when compared with traditional compost types.

Vermi-compost had the highest CEC, an evolving indicator due to the Organic Matter (OM) humification (Venegas et al., 2004), whereas nursery compost had the lowest value. Shi-Wei and Fu-zhen (1991); Holcombe and Longfellow (1995) found out that the worm castings in the vermi-compost have nutrients that are $97 \%$ utilizable by plants and the castings have a mucous coating which allows the nutrients to time release. Red-worm castings contain a high percentage of humus, which helps soil particles form into clusters, which again create channels for the passage of air and improve its capacity to hold water. Shi-Wei and Fu-zhen (1991); Holcombe and Longfellow (1995) revealed that Humic acid present in humus provides binding sites for the plant nutrients, resulting in a strong adsorption and retention of nutrients.

Table 3. Mean value of chemical properties of compost treatments.

\begin{tabular}{|lcccccccccc|}
\hline Source & $\boldsymbol{E C}$ & $\boldsymbol{p H}$ & $\boldsymbol{a v . P}$ & $\boldsymbol{O C}(\boldsymbol{\%})$ & $\boldsymbol{T N}(\boldsymbol{\%})$ & $\boldsymbol{e x . K}$ & $\boldsymbol{e x . N a}$ & $\boldsymbol{e x . C a}$ & $\boldsymbol{e x . M g}$ & $\boldsymbol{C E C}$ \\
\hline Farmers' & 0.27 & 8.27 & 146.61 & 9.72 & 0.80 & 1.40 & 0.88 & 0.33 & 0.22 & 2.38 \\
\hline Garden & 0.27 & 7.47 & 153.32 & 10.67 & 0.87 & 1.97 & 1.13 & 0.38 & 0.18 & 5.15 \\
\hline Nursery & 0.21 & 7.53 & 113.83 & 5.04 & 0.41 & 0.50 & 0.50 & 0.78 & 0.12 & 2.29 \\
\hline Vermi & 0.26 & 7.50 & 159.64 & 10.63 & 0.87 & 1.31 & 0.90 & 0.88 & 0.46 & 6.47 \\
\hline
\end{tabular}

Key: EC (Electrical Conductivity, dSm ${ }^{-1}$ ), ava.P (available Phosphorus, ppm), Ex.K (exchangeable Potassium, $\%)$, ex.Na (exchangeable Sodium, \%), ex.Ca (Exchangeable Calcium) \& ex. Mg (exchangeable Magnesium, $\%)$.

The highest $\mathrm{pH}$ was recorded in the farmers' compost (8.27), which was $10.7,9.8$ and 10.3 percent higher than the conventional, nursery and vermi-composts respectively. When compared with the pH classes of Santamaria-Romero and Ferrera-Cerrato (2002), the pH of garden and vermi-composts were within the neutral range (6.5-7.5) while the farmers' and nursery composts were within the range of moderately alkaline (7.5-8.5) classes. 
In contrast to the findings of Nadi et al. (2011), who showed an increase in Cupper $(\mathrm{Cu})$, Manganese $(\mathrm{Mn})$ and Iron $(\mathrm{Fe})$ contents due to vermi-composting; there was no significant difference on these contents among the treatments under investigation (Table 2). For all treatments, the $\mathrm{C} / \mathrm{N}$ ratio was low (12.22) which is below the threshold (about 30) suggested by Edwards and Bater (1992). This suggests that as the $\mathrm{C} / \mathrm{N}$ ratio (Table 4) is lower than the threshold, mineralization is faster, nutrients eventually become available and a large amount of $\mathrm{N}$ is lost (Capistran et al., 2001).

Table 4. Mean value of micro-nutrients from different compost sources.

\begin{tabular}{|lccccc|}
\hline Source & $\boldsymbol{C u}(\boldsymbol{\%})$ & $\boldsymbol{M n} \mathbf{( \% )}$ & $\boldsymbol{F e}(\boldsymbol{\%})$ & $\boldsymbol{Z n ~ ( \% )}$ & $\boldsymbol{C} / \boldsymbol{N}$ \\
\hline Farmers' & 0.05 & 0.04 & 0.06 & 0.08 & 12.20 \\
\hline Garden & 0.05 & 0.04 & 0.07 & 0.11 & 12.22 \\
\hline Nursery & 0.03 & 0.04 & 0.06 & 0.08 & 12.19 \\
\hline Vermi & 0.05 & 0.05 & 0.07 & 0.38 & 12.22 \\
\hline
\end{tabular}

The contribution of vermi-compost was also evaluated by making comparisons with the conventional/garden compost. The available Phosphorus (ava.P), exchangeable Calcium (ex.Ca), exchangeable Magnesium (ex.Mg) in vermi-compost was respectively 4.1, 131.6 and 155.6 percent higher as compared to the conventional/garden compost. Many researchers (e.g. PerzMurcia et al., 2006; Munroe, 2007; Sinha et al., 2010) have also compared the benefits of vermicomposting with the conventional composting and concluded that vermi-compost provided extra phosphorus (1.55-2.25 percent). This also corresponds with the study of Atiyeh et al. (2000a\&b) in which Phosphorus $(\mathrm{P})$ and Magnesium $(\mathrm{Mg})$ were significantly increased by adding vermicompost to soil as compared to conventional compost. Moreover, this was supported by the findings of Nagavallemma et al. (2004) who showed a 0.68 percent increase in Phosphorus content by vermi-composting as compared to the conventional composting.

Unlike the findings of Atiyeh et al. (2000a\&b); Perz-Murcia et al. (2006); Sinha et al. (2010) who showed that exchangeable potassium (ex.K) was 1.55 - 95 percent higher in vermi-compost, the ex.K in this study showed 33.5 percent less in vermi-compost. This matches with the findings of Nagavallemma et al. (2004) and Hernández et al. (2010), in which ex.K was respectively 0.25 and 2.6 percent lower in vermi-compost. In contrast to the study of Kalantari et al. (2010) and Las Cruces (2001), the EC, OC and Nt contents and C/N of vermi-compost did not show any difference from the garden compost. 


\section{CONCLUSION}

The findings of the chemical analysis showed that the $\mathrm{pH}$, exchangeable Magnesium (ex.Mg), Available Phosphorus (ava.P), Cation Exchange Capacity (CEC) and Exchangeable Potassium (ex.K) had significantly varied $(\mathrm{p}<0.05)$ among the composting techniques. The ava.P, OC, TN, ex.Mg and CEC were highest in vermi-compost while the lowest value was recorded in nursery compost. The possible reason for the increased CEC was that red-worm castings contain a high percentage of humus, which helps soil particles form into clusters, which again create channels for the passage of air and improve its capacity to hold water. This indicates that vermi-compost is potentially better growth medium amendment when compared with traditional compost types. The use of vermi-compost is, therefore, very helpful in terms of providing beneficial soil nutrients as compared to other compost types.

In contrast to the other chemical and biological properties, the highest $\mathrm{pH}$ was recorded in the farmers' compost (8.27), which was 10.7, 9.8 and 10.3\% higher than the conventional, nursery and vermi-composts respectively. The $\mathrm{pH}$ of garden and vermi-composts were within the neutral range (6.5-7.5) while the farmers' and nursery composts were within the range of moderately alkaline (7.5-8.5) classes. For all treatments, the $\mathrm{C} / \mathrm{N}$ ratio was low (12.22) which are below the threshold (about 30). This suggests that as the $\mathrm{C} / \mathrm{N}$ ratio is lower than the threshold, mineralization is faster, nutrients eventually become available and a large amount of $\mathrm{N}$ is lost. The Cupper $(\mathrm{Cu})$, Manganese $(\mathrm{Mn})$, Zinc $(\mathrm{Zn})$ and Iron $(\mathrm{Fe})$ contents of the treatments under investigation did not show a significant difference.

This research, however, did not evaluate the chemical and biological properties of the individual composting materials. Furthermore, the focus of the study was only on the chemical and biological properties of the products but an economic analysis, which is an important factor for the sustainability of the technologies, was not considered. It is, therefore, recommended that further investigation on the contents of composting materials and cost-benefit analysis for the use of worms is very important for effective utilization of the vermi-compost.

\section{ACKNOWLEDGEMENTS}

The authors thank Mekelle University Research and Publication Office for the financial and logistics support. The authors feel great pleasure to express a special gratitude to the farmers and nursery foremen of the study sites. 


\section{REFERENCE}

Abrar, S., Morrissey, O \& Payner, T. 2004. Aggregate Agricultural Supply Response in Ethiopia: a farm-level analysis. Journal of International Development, 16: 605 - 620.

Aira, M., Monroy, F., Dominguez J \& Mato, S. 2002. How earthworm density affects microbial biomass and activity in pig manure. European Journal of Soil Biology, 38: 7-10.

Atiyeh, R.M., Dominguez, J., Sobler, S \& Edwards, C.A. 2000a. Changes in bio-chemical properties of cow manure during processing by earthworms (Eisenia andrei) and the effects on seedling growth; Pedobiologia, 44: 709 - 724.

Atiyeh, R.M., Subler, S., Edwards, C.A., Bachman, G., Metzger, J.D \& Shuster, W. 2000 b. Effects of Vermicomposts and Composts on Plant Growth in Horticultural Container Media and Soil. Pedobiologia, 44: 579 - 590.

Belay Tegene, 1996. Characteristics and Landscape Relationships of Vertisols and Vertic Luvisols of Melbe, Tigray, Ethiopia. Ethiopia Journal of Science, 19: 93 - 115.

Bezabih Emana, Hadera Gebremedhin \& Nigatu Regassa. 2010. Impacts of Improved Seeds and Agrochemicals on Food Security and Environment in the Rift Valley of Ethiopia: Implications for the Application of an African Green Revolution. Drylands Coordination Group Report No. 5602.

Capistran, F., Aranda, E \& Romero, J.C. 2001. Recycle, Composting and Vermi-composting Handbook. Ecology Institute A.C. (ed.). Veracruz, Mexico, 150p.

Chaoui, H.I., Edwards, C.A., Brickner, A., Lee, S.S \& Arancon, N.Q. 2002. Suppression of the plant diseases, Pythium (damping-off), Rhizoctonia (root rot) and Verticillilum (wilt) by vermicomposts. Proceedings of Brighton Crop Protection Conference - Pests and Diseases, Brighton, UK. ISBN 1-901396-62-2.

Christensen, L.M \& Fulmer, E.I. 1927. A Modified Kjeldahl Method for the Determination of the Nitrogen Content of Yeast. Plant Physiology, 2: 455-460.

CSA, 2008. Summary and Statistical Report of the 2007 Population and Housing Census Results. Population size by age and sex. Central Statistical Agency, Addis Ababa, Ethiopia.

De Brito, A.M.A., Gagne, S \& Antoun, H. 1995. Effect of compost on rhizosphere microflora of the tomato and on the incidence of plant-growth promoting rhizobacteria. Applied and Environmental Microbiology, 61:194-199. 
Edwards, C.A. 1998. The use of earthworm in the break down and management of organic wastes. In: C.A. Edwards (ed.) Earthworm Ecology. St. Lucie Press, Boca Raton, pp. 327-357.

Edwards, C.A \& Bater, J.E. 1992. The use of earthworms in environmental management. Soil Edwards, C.A and J.E. Bater. The use of earthworms in environmental management. Soil Biol. and Biochem, 24: 1683-1689.

Fredu Nega. 2008. Poverty, Asset Accumulation, Household Livelihood and Interaction with Local Institutions in Northern Ethiopia. Dissertations De Agricultura. Katholieke University of Leuven, pp. 232.

Gebreyohannes Girmay, Nyssen, J., Poesen, J., Bauer, H., Merckx, R., Mitiku Haile \& Deckers, J. 2012. Land reclamation using reservoir sediments in Tigray, northern Ethiopia. Soil Use and Management, 28: 113-119.

Girmay Tesfay. 2006. Agricultural Resource Management and Institutions. A socioeconomic analysis of households in Tigray, Ethiopia. Ph.D. Dissertation. Department of Social Sciences, Development Economics Group, Wageningen University and Research Centre, the Netherlands.

Hailu Araia. 2010. The Effect of Compost on Soil Fertility Enhancement and Yield Increment under Smallholder Farming- a Case of Tahtai Maichew District - Tigray Region, Ethiopia. PhD thesis. Universitat Hohenheim (310), D-70593 Stuttgart.

Hailu Araya \& Edwards, S. 2006. The Tigray Experience: A success story in sustainable agriculture. Environment and Development Series 4, Third World Network: Penang, 33p.

Hernández, A., Castillo, H., Ojeda, D., Arras, A., López, J \& Sánchez, E. 2010. Effect of Vermicompost and Compost on Lettuce Production. Chilean Journal of Agricultural Research, 70: 583-589.

Hoitink, H.A.J \& Fahy, P.C. 1986. Basis for the control of soil-borne plant pathogens with composts. Annual Review of Phytopathology, 24: 93-114.

Holcombe, D \& Longfellow, J.J. 1995. Blue Print for a successful Vermiculture Compost System: Construction drawings, Operators guide, Operation Plan, Site License. OSCR. VERMICO.

Hunting, 1975. Central Tigre Developments Study, Tigre Region, Ethiopia. Soils and Land Classification. Working Paper I: Hunting Technical Services Ltd. 
Institute for Sustainable development (ISD) and Environmental Protection Authority (EPA), 2009. Natural fertilizer: a Tigrigna book. Addis Ababa, Ethiopia.

ISO. 1994. Soil Quality - Determination of exchangeable acidity in barium chloride extracts. International Organization for Standardization. Geneva, Switzerland, 5p.

ISO. 1995. Soil Quality - Extraction of trace elements soluble in aqua regia. International Organization for Standardization. Geneva, Switzerland, 6p.

Kalantari, S., Hatami, S., Ardalan, M.M., Alikhani, H.A \& Shorafa, M. 2010. The effect of compost and vermicompost of yard leaf manure on growth of corn. African Journal of Agricultural Research, 5(11): 1317-1323.

Kale, R.D. 1998. Earthworm Cinderella of Organic Farming. Prism Book Pvt Ltd, Bangalore, India, 88p.

Kassa Teka, Van Rompaey, A \& Poesen, J. 2010. Land suitability Assessment for Different Irrigation Methods in Korir Watershed, Northern Ethiopia. Journal of the Drylands, 3: 214-219.

Kassa Teka \& Mulu Haftu, 2012. Land Suitability Characterization for Crop and Fruit Production in Midlands of Tigray, Ethiopia. Momena Ethiopia Journal of Science, 7: 6476.

Kassa Teka Belay., Van Rompaey, A., Poesen J., Van Bruyssel S., Deckers, J \& Kassa Amare, 2014. Spatial Analysis of Land Cover Changes in Eastern Tigray. Land Degrad. Develop., doi: 10.1002/ldr.2275.

Las Cruces, N.M. 2001. Vermi-composting: Guide H-164. Cooperative Extension Service College of Agriculture and Home Economics, New Mexico State University.

McKeague, J.A. 1976. Manual of Soil Sampling and Methods of Analysis. Soil Research Institute.

McLean, E.O. 1982. Soil pH and lime requirement. In: A.L. Page et al. (eds.) Methods of soil analysis. Part 2, 2nd ed. Agron. Monogr., 9. ASA and SSSA, Madison, Wis., pp. 199224.

Mugwe, J., Mugendi, D., Kungu, J \& Mucheru-Muna, M. 2007. Effects of plant biomass, manure and inorganic fertilizer on maize yield in the central highlands of Kenya. African Crop Science Journal, 15(3): 111-126. 
Munroe, G. 2007. Manual of On-farm Vermicomposting and Vermiculture. Pub. of Organic Agriculture Centre of Canada, 56p.

Nadi, M., Golchin, A., Mozafari, V., Saeidi, T \& Sedaghati, E. 2011. The Effects of Different Vermicomposts on the Growth and Chemical Composition of the Pistachio Seedlings. Journal of Research in Agricultural Science, 7: 59-69.

Nagavallemma, K.P., Wani, S.P., Stephane, L., Padmaja, V.V., Vineela, C., Babu, R.M \& Sahrawat, K.L. 2004. Vermicomposting: Recycling wastes into valuable organic fertilizer. Global Theme on Agrecosystems. Report, No. 8, International Crops Research Institute for the Semi-Arid Tropics (ICRISAT), Hyderabad, India.

Nigussie Haregeweyn, Poesen, J., Nyssen, J., De Wit, J., Mitiku Haile, Govers, G \& Deckers, S. 2006. Reservoirs in Tigray (northern Ethiopia): characteristics and sediment deposition problems. Land Degradation \& Development, 17: 211-230.

Nyssen, J., Naudts, J., De Geyndt, K., Mitiku Haile, Poesen, J., Moeyersons, J \& Deckers, J. 2008. Soils and land use in the Tigray highlands (northern Ethiopia). Land Degradation and Development, 19: 257-274.

Olsen, S.R., Cole, C.V., Watanabe, F.S \& Dean, L.A. 1954. Estimation of available phosphorus in soils by extraction with sodium bicarbonate. USDA circular 939. U.S. Govt. Printing Office, Washington D.C., 19p.

Perz-Murcia, M.D., Moral, R., Moreno-Caselles, J., Perez-Espinosa, A \& Paredes, C. 2006. Use of composted sewage sludge in growth media for broccoli. Bioresource Technology, 97(1): 123-130.

Santamaria-Romero, S \& Ferrera-Cerrato, R. 2002. Population Dynamics of Eisenia Andrei in different Organic Wastes. Terra, 20: 303 - 310.

Saradha, T. 1997. The culture of earthworms in the mixture of pond soil and leaf litter and analysis of vermifertilizer. J. Ecobiology, 9(3): 185-188.

Satchel, J.E \& Martin, K. 1984. Phosphatase Activity in Earthworm Feces. J. Soil Biology and Biochemistry, 16: 191-194.

Scheuerell, S \& Mahaffee, W. 2002. Compost Tea: Principles and Prospects for Plant Disease Control. Compost Science and Utilization, 10: 313-338.

Shi-wei, Z \& Fu-zhen, H. 1991. The Nitrogen Uptake Efficiency from 15N Labeled Chemical Fertilizer in The Presence of Earthworm Manure (cast). In: G.K. Veeresh., D. Rajagopal 
and C.A. Viraktamath (eds.). Advances in Management and Conservation of Soil Fauna. Oxford and IBH publishing Co., India, pp. 539-542.

Sinha, R.K., Valani, D., Chauhan, K \& Agarwal, S. 2010. Embarking on a second green revolution for sustainable agriculture by vermiculture biotechnology using earthworms: Reviving the dreams of Sir Charles Darwin. Journal of Agricultural Biotechnology and Sustainable Development, 2: 113-128.

Swedish Society for Nature Conservation (SSNC). 2008. Report on Ecological in EthiopiaFarming with nature increases profitability and reduces vulnerability. Stockholm, Sweden, 28p.

Tomati, V \& Galli, E. 1995. Earthworms, Soil Fertility and Plant Productivity. Acta Zoologica Fennica, 196: 11-14.

Van de Wauw, J., Baert, G., Moeyersons, J., Nyssen, J., De Geyndt, K., Nurhussein Taha, Amanuel Zenebe, Poesen, J \& Deckers, J. 2008. Soil-Landscape Relationships in the Basalt-Dominated Highlands of Tigray, Ethiopia. CATENA, 75: 117-127.

Venegas, G.J., Cajuste, L.J., Trinidad, S.A., Gavi, R.F \& Snchez, G.P. 2004. Behavior of the pH and cation exchange capacity in organic wastes with different humification rate. In: Anonymous (eds.). Proceedings of the 1st Intl. Congress of the Vermi-composting and Organic Wastes, Guadalajara, Jalisco, Mexico.

Weltzien, H.C. 1989. Some effects of composted organic materials on plant health. Agriculture Ecosystems and Environment, 27: 439-446.

World Bank. 2007. World Bank Fact Index Country Report: Ethiopia. www.worldbank.org/ en/country/ethiopia/overview. 